\begin{tabular}{lll} 
GEOFIZIKA VOL. $37 \quad 2020$ \\
\hline
\end{tabular}

DOI: https://doi.org/10.15233/gfz.2020.37.3

Original scientific paper

\title{
Calculating the characteristics of flash floods on small rivers in the Mountainous Crimea
}

\author{
Valeriya Ovcharuk, Eugene Gopchenko, Olena Todorova and Kateryna Myrza \\ Hydrometeorological Institute, Department of Land Hydrology, Odessa State Environmental \\ University, Odessa, Ukraine
}

Received 16 November 2019, in final form 29 March 2020

\begin{abstract}
The maximal surface runoff from territory of the Crimean Mountains is represented as a runoff of small rivers that flow through the western and eastern part of the northern slope and from the southern coast. The materials from 54 water gauging stations (WGS) were used to characterize the maximum runoff during rain and meltwater-rain floods on the rivers in the Crimean Mountains. A modified reduction structure of a calculation formula was used for valuation of the maximal runoff of different origin flash flood for rivers at the Mountainous Crimea. The main parameters of the proposed model are summarized as dependencies on the average height of the catchments and generalized in the form of a map. It is also possible to use the second variant of the suggested method taking into account the factor of underlying surface is introduced. Comparison of the calculated values of maximal runoff shows good convergence with both the initial information, and the largest values in the observation period.
\end{abstract}

Keywords: maximum runoff, flash flood, isochrone

\section{Introduction}

At the present time, in the period of global climate change, scientists in many countries of the world notice increased cases of extreme natural phenomena. Rain floods, especially flash floods, are classified as hazardous hydrological phenomena and often result in catastrophic consequences. In October 2015, the EU-funded project 'Support to Ukraine in approximation of the EU environmental acquis' was launched. The main focus of the project is management of water and natural resources, in particular the implementation of the water-related directives of the European Union - the Water Framework Directive 2000/60/EC and the Floods Directive 2007/60/EC. The Floods Directive envisages, first of all, determination of the zones of possible flooding in the course of floods. Therefore, the problem of identification of the maximum runoff of the ungauged rivers, especially the ones with rare probability of excess arises. 
Mathematical models are very important in planning water resources management and, consequently, diverse types of models with divergent degrees of complexity have been developed and are still being improved by scientists from various countries (Zhao et al., 1980; Singh, 1988; Bergstorm, 1992; Kan et al., 2017). Nowadays, scientific literature presents more advanced conceptual models with distributed parameters and even models with the application of artificial neural networks (Sajikumar and Thandaveswara, 1999; Tokar and Markus, 2000), that makes it possible to determine the river runoff at particular catchment areas with sufficient accuracy, using a large amount of source information, although, for ungauged catchments, such models are not applicable.

In Ukraine, the development of methods for determination of the maximum runoff of ungauged rivers has been given a great attention at various levels, from university to nationwide research (Gopchenko and Ovcharuk, 2006, 2015; Gorbachova and Nabyvanets, 2012; Hrebin, 2010; Kyndiuk, 2003; Loboda and Bozhok, 2016). Nevertheless, in spite of the accumulated vast experience, there are many contradictions in the scientific and methodological approaches to calculation of the maximum runoff characteristics during rain floods and spring floods.

Analysis of the scientific and methodological base shows that it is not wellgrounded and needs improvement. Therefore, it is necessary to pay attention to standardization of the characteristics of different origin floods on a more comprehensive theoretical basis. This is especially true of geometric models, which are based on the hydrographs of slope and channel runoff (or only the channel one), as well as the models of isochrones.

The presented research is devoted to standardization of the maximum runoff characteristics during rain and meltwater-rain flash floods for rivers in the Mountainous Crimea based on the modified reduction structure, which was obtained directly from the model of channel isochrones.

\section{Study area}

The study area is a mountain part of the Crimean Peninsula, located within the $44^{\circ} 23^{\prime}$ (Cape Sarych) and $46^{\circ} 15^{\prime}$ (the Isthmus of Perekop) N and $32^{\circ} 30^{\prime}$ (Cape Karamrun) and $36^{\circ} 40^{\prime}$ (Cape Fonar) E. The Mountainous Crimea stretches along the Black Sea coast on the southeastern and southern parts of the Crimean Peninsula; the length of this mountain system is $150-160 \mathrm{~km}$, maximum width is $50-60 \mathrm{~km}$ (Fig. 1).

Belbek, Chorna, Bijuk-Karasu and Salhyr are the largest and most fullflowing rivers of the Crimea. Hydrographic network of the Mountainous Crimea is developed extremely unevenly; here you can find vast areas that do not have permanent water streams, in other areas very small rivers and streams are very frequent. Given all the rivers and temporary watercourses, the average density of the river network for the whole territory will be $0.22 \mathrm{~km} / \mathrm{km}^{2}$. 


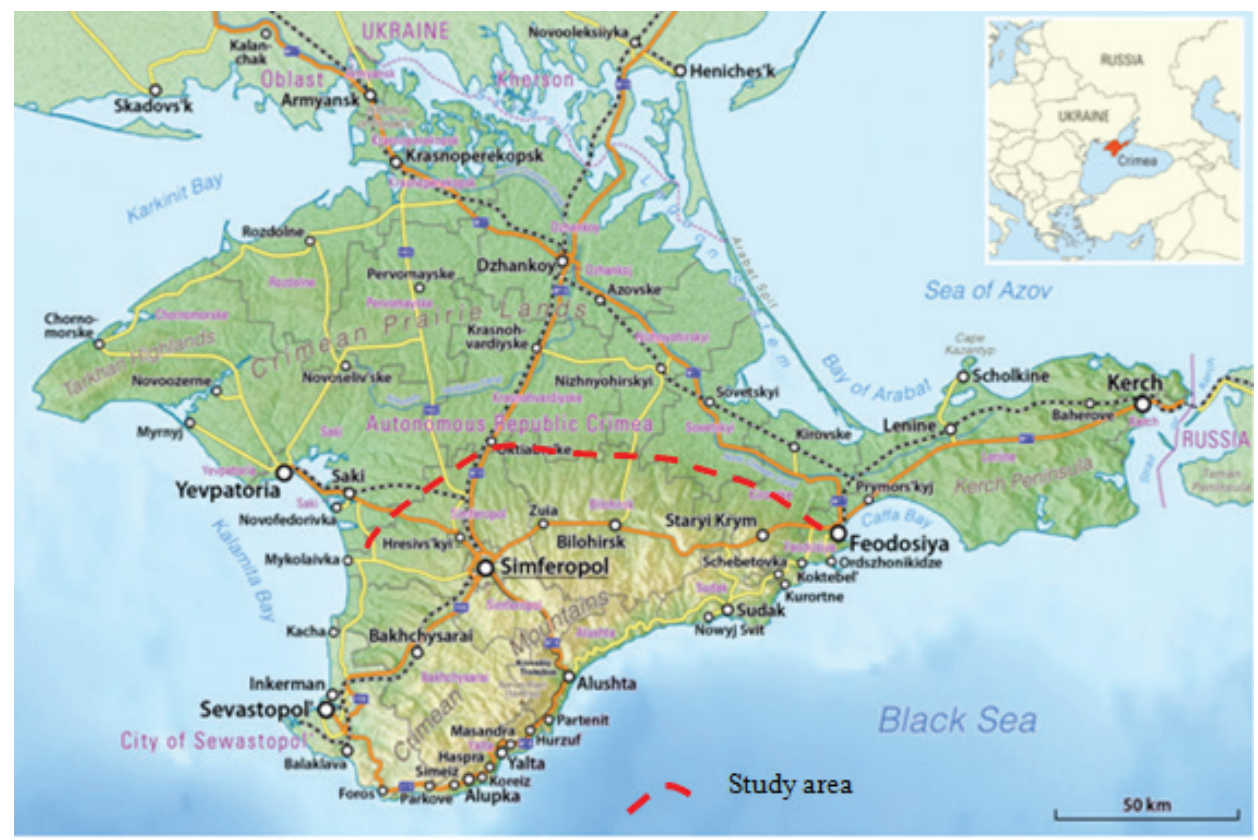

Figure 1. Location map of Crimea.

The river network reaches the largest development at 600-1,100 $\mathrm{m}$ above sea level, where the majority of the sources that give rise to streams and rivers are concentrated. The density of the river network here is $0.7 \mathrm{~km} / \mathrm{km}^{2}$. In Crimea, $80-85 \%$ of the annual precipitation falls as rain. Rivers in the Mountainous Crimea cause flooding rains, which are accompanied by the demolition of eroded rocks. Rainstorms, at the same time, never cover the entire Crimea. They typically fall over a minor area. Most often heavy rains and downpours are all day long. Floods at the rivers in the warm season are not observed at the same time.

For example, in the north-western slope of the Crimean Mountains, the maximum discharges at the rivers in a warm period are observed most frequently in April-July, at the rivers in the southern coast of Crimea - from April to August, and at the rivers in the eastern part of the northern slope in the spring.

At the catchment areas in the Mountainous Crimea, the most frequent maximum daily rainfall, forming flash floods, is observed within the range of 71$90 \mathrm{~mm}(27,3 \%)$, precipitation within the range of 31-70 $\mathrm{mm}$ (with the total frequency of their occurrence comprising 40.9\%) is also typical for the formation of floods during the warm period (Ovcharuk and Todorova, 2016).

According to Zaikov's (1944) classification by the water regime, the rivers in the Crimea belong to rivers with a flood regime of the Crimean subtype. Two 


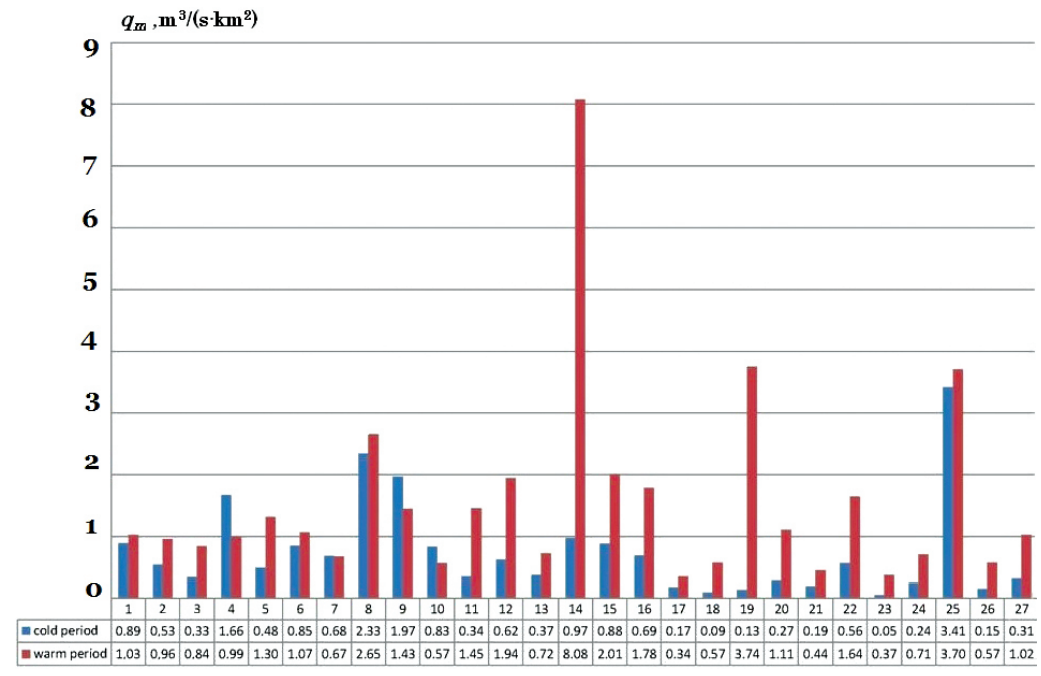

Figure 2. Comparison of the maximum water runoff during the warm and cold flood seasons for rivers in the Mountainous Crimea.

periods are distinguished within the annual variation of water levels in the rivers: a meltwater-rain or cold period floods and rain floods of a warm period. From 80 up to $95 \%$ of the total annual runoff falls on the flood period. In the summer, the Crimean rivers often dry up, but when heavy rain falls, they turn into tumultuous streams. Water regime of the rivers in the Mountainous Crimea due to its relatively small height is characterized by generally rather uniform hydrological conditions. The water regime is primarily affected by cracked limestones, which regulate the surface and subsurface runoff. In addition, one of the peculiarities of the Crimean Rivers is a severe deformation of their channels. Finally, the natural regime of most rivers is distorted by the regulatory influence of artificial reservoirs, as well as by the water intake for irrigation. In this regard, there are differences in water regime for various watercourses and even along the length of the same river.

The maximum runoff for most rivers is observed in the summer-autumn period, and for some of them it can exceed a winter-spring runoff 2-4 times (Belbek, Demerdzhi, Zuya, etc.). However, there are cases when the winter floods were higher than the summer ones (Fig. 2).

Consequently, floods on the Crimean Rivers are observed both in the warm and cold seasons. In winter, flooding occurs as a result of snow melting, which is usually accompanied by precipitation, and in summer - as a result of intense rainfall. The water flow at the Crimean Rivers dramatically increases during the flood. Absolute maxima are formed during the warm period upon the emer- 
gence of heavy rains and can exceed the average annual water runoff 200-400 times.

Considering the potential threat posed by flash floods to the population, the development of modern methods to calculate the maximum river runoff is a topical scientific and applied task for the area of the Crimean Mountains.

\section{Methodology and data}

The calculation of the maximum runoff during floods in the studied area is based on the theory of channel isochrones, implemented in the form of a twooperator model for the river runoff formation, developed at Odessa State Environment University. Its advantage is that it is universal both in terms of the genetic type of floods, and the dimension of catchment areas.

The 'operators' model (Gopchenko and Ovcharuk, 2000) makes it possible to determine separately the characteristics of the slope inflow (the depth of flood runoff, the duration of the slope inflow and the temporal non-uniformity of slope inflow to the channel network) and to take account of the natural process of precipitation transformation into the river bed in the structure of 'slope inflow - channel runoff. The rationing of maximum runoff characteristics during rain floods at the rivers in the Mountainous Crimea is based on a modified reduction structure that was derived directly from the 'operators' model.

According to the authors (Gopchenko and Ovcharuk, 2006; Ovcharuk et al., 2018), in contrast to the standard formulas of the reduction type, the method of isochrones, applied in substantiation of the structure (1), makes it possible to more fully take into account all the runoff factors, which in this formula are represented by the constituents of the slope modulus $q_{m}^{\prime}$ :

$$
q_{m}=\frac{q_{m}^{\prime}}{(A+1)^{n_{1}}},
$$

where $A$ is a catchment area, $\mathrm{km}^{2}, q_{m}^{\prime}$ is a maximum modulus of the slope inflow and $n_{1}$ is a coefficient of reduction of maximum runoff modulus with an increase in the catchment area.

Formula (1) should be considered, in essence, as a generalized version of the single-modal geometry of spring and rain flood hydrographs, but only for the case if the variability in the water inflow from the slopes $T_{0}$ for the area is integrally small and can be averaged.

Under these conditions, $q_{m}^{\prime}$ is a maximum modulus of the slope inflow and is equal to:

$$
q_{m}^{\prime}=\frac{n+1}{n} \frac{1}{T_{0}} Y_{m}=k_{0} Y_{m}
$$


where $\frac{n+1}{n}$ is a coefficient of time nonuniformity of slope inflow, $T_{0}-$ a duration of slope inflow, hours, $Y_{m}-$ a runoff depths, mm, $k_{0}-$ a transformation coefficient for the slope runoff.

According to the model of channel isochrones, the formula (3) in the editorship of Gopchenko (2000) is basic for them.

$$
q_{m}=q_{m}^{\prime} \Psi\left(\frac{t_{p}}{T_{0}}\right) \varepsilon_{A}
$$

where $\varepsilon_{A}$ is a coefficient of channel and flood plain regulation that depends on the catchment dimension; $\Psi\left(\frac{t_{p}}{T_{0}}\right)$ - a transformation function influenced by a
channel lag.

Comparison of (1) and (3) shows that

$$
\Psi\left(\frac{t_{p}}{T_{0}}\right) \varepsilon_{A}=\frac{1}{(A+1)^{n_{1}}},
$$

that is, when averaging $T_{0}$ over the area, the equation (3) reduces to the known structure of the reduction empirical formula.

Formula of the form (1) is the result of averaging $T_{0}$ over the area. As can be seen from (2), this condition is not obligatory, but then $T_{0}$ is not subject to averaging, and is to be generalized over the area by other methods. In particular, one of the variants of generalization is the mapping of values and if there is a change in $T_{0}$ and $Y_{m}$ over the area in one direction then the reduction formula takes the form (1):

$$
q_{m}=\frac{q_{m}^{\prime}}{(A+1)^{n_{1}}}
$$

where $q_{m}^{\prime}$ is a maximum module of the slope inflow, which is equal to

$$
q_{m}^{\prime}=0.28 \frac{n+1}{n} \frac{1}{T_{0}} Y_{1 \%},
$$

where 0.28 is a coefficient of dimension, $Y_{1 \%}-$ a runoff depths $1 \%$ probability.

It is the authors' opinion that the advantage of this structure is its simplicity and a small number of calculated parameters. On the other hand the structure (6) refers to the method of isochrones that makes it possible to more fully take into account all the runoff formation factors, which in this formula are represented by the constituents of the slope inflow module $q_{m}^{\prime}$.

Data. To characterize the maximum runoff during flash floods (the water layers during rain and meltwater-rain floods and the maximum water discharge) on the rivers in the Crimean Mountains the materials of observations for a long- 


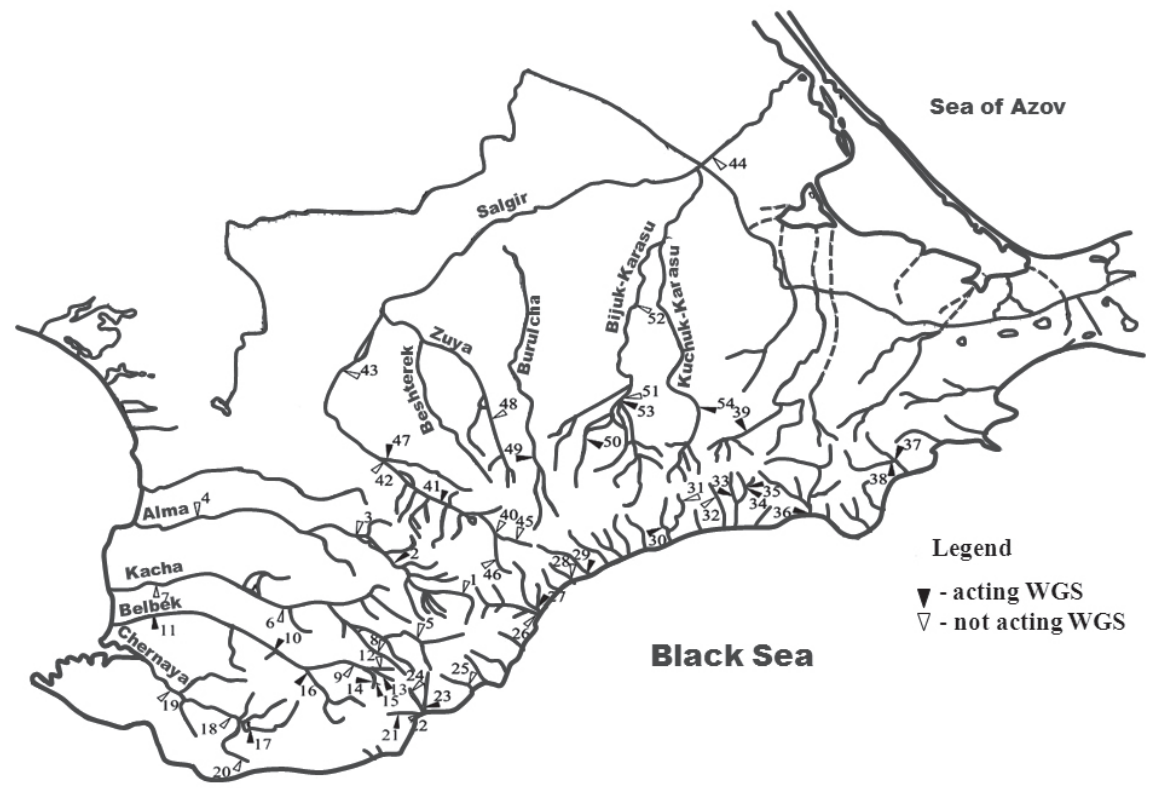

Figure 3. Location map of the water gauging stations (WGS) in Crimean Mountains.

term period (from the beginning of observations up to 2010) for 54 water gauging station (WGS) were used (Fig. 3).

The area of water basins varies from 0.32 to $3540 \mathrm{~km}^{2}$; the average altitude of watersheds ranges from 340 to $980 \mathrm{~m}$. Analyzing the range of catchment areas of the rivers under observation it can be noted that most of them belong to the category of small rivers - 53 of 54 or $98,2 \%$. At the rivers, which can be classified as medium-sized, only 1 station operates which is $1.9 \%$ of their total number. Duration of the observation series for the water runoff at the studied area as a whole ranges from 17 to 82 years. At the same time, the majority of stations $(64.8 \%)$ have a series of observations with duration from 21 to 50 years, 16 stations $(29.6 \%)$ - more than 50 years; at 4 stations $(7.14 \%)$ the hydrological series comprise from 11 to 20 years.

To study possible trends in the time series the linear regression method was used and the assessment of the trend reliability was performed by means of the Pearson correlation coefficient.

\section{Results}

To study the possible changes in time series of the air temperature and precipitation during the warm period of the year in the Crimean Peninsula the chronological graphs, given in Figs. 4 and 5, were built. 
a) 35
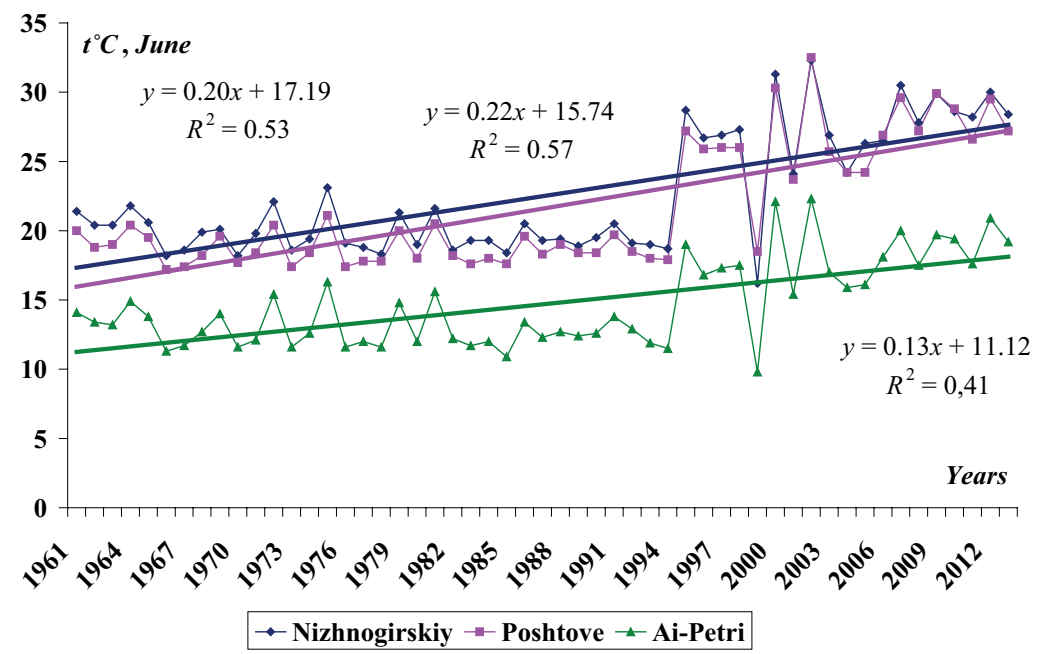

b)

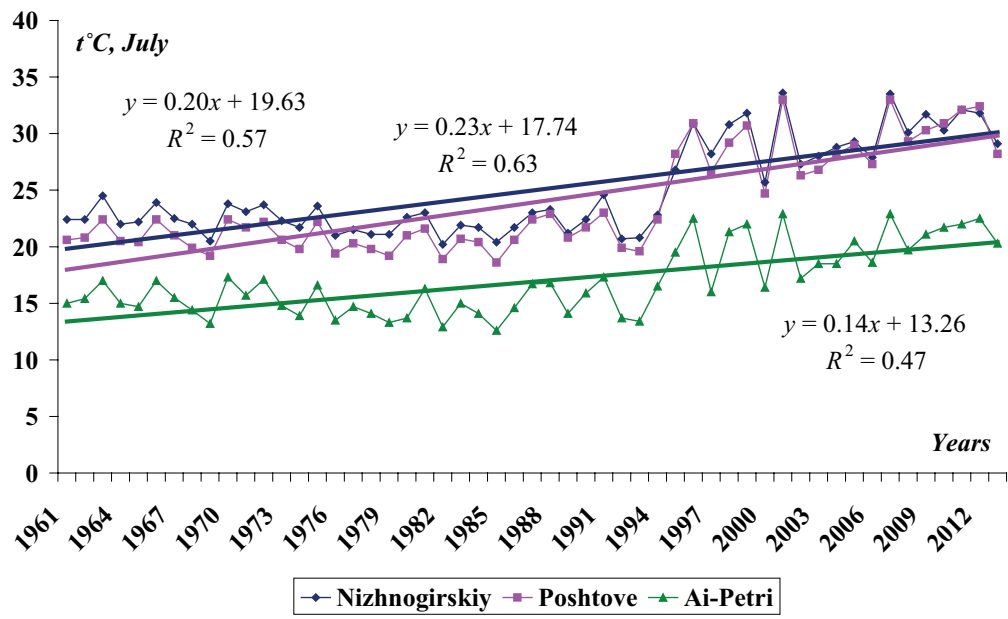

Figure 4. The time series of the air temperature during the warm period of the year at the meteorological stations in the mountainous part of the Crimean Peninsula.

Analyzing the time series of the air temperature it should be noted that no particular changes were observed from 1961 to 1989-1990, but since 1994 there was an active temperature increase - in June and July (Fig. 4a and Fig. 4b). Correlation coefficients in all cases are significant. Unlike the air temperature in the time series of precipitation for June and July significant trends are observed only in $50 \%$ of cases. That is, there was a certain redistribution of precipitation between months leading to an increase in rainfall at the north-western slope in June (Fig. 5a) and at two other slopes in July (Fig. 5b). 

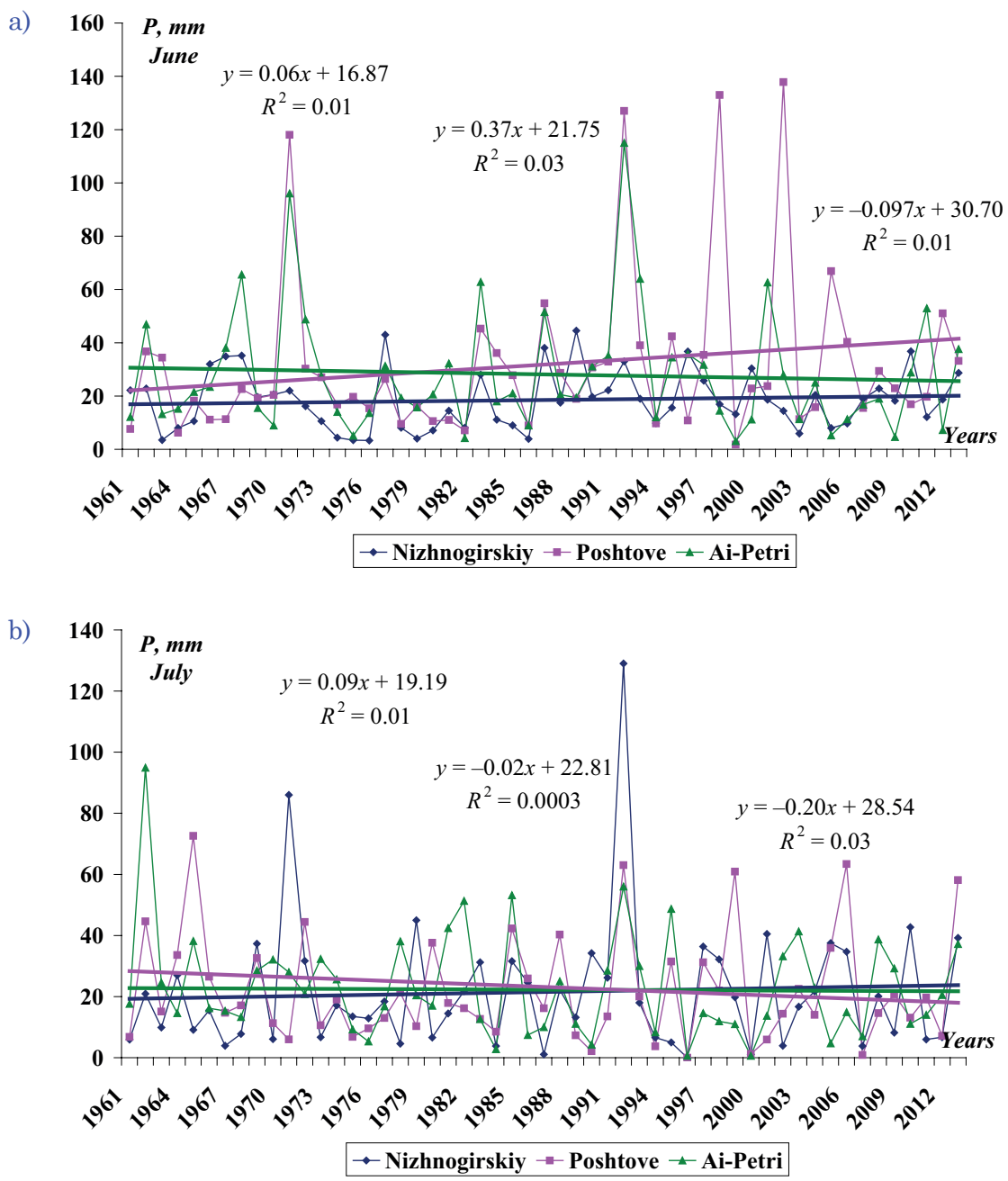

Figure 5. The time series of the precipitation during the warm period of the year at the meteorological stations in the mountainous part of the Crimean Peninsula.

Fig. 6 presents a map of the territorial distribution of the maximum water discharges during rain floods within all period of observations. The values of absolute maximums on the main rivers in the Crimean Mountains and the years in which they were observed represented by the points of WGS. As well illustrated in Fig. 6, the values of maximum water discharges fluctuate within a rather wide range - from $13 \mathrm{~m}^{3} / \mathrm{s}$ (the Kuchuk-Uzenbash River - Mnogorichia v.) to $414 \mathrm{~m}^{3} / \mathrm{s}$ (Belbek River - Fruktove v.). At first glance, there are practically no regularities in the distribution of these maxima both in space and in time. 


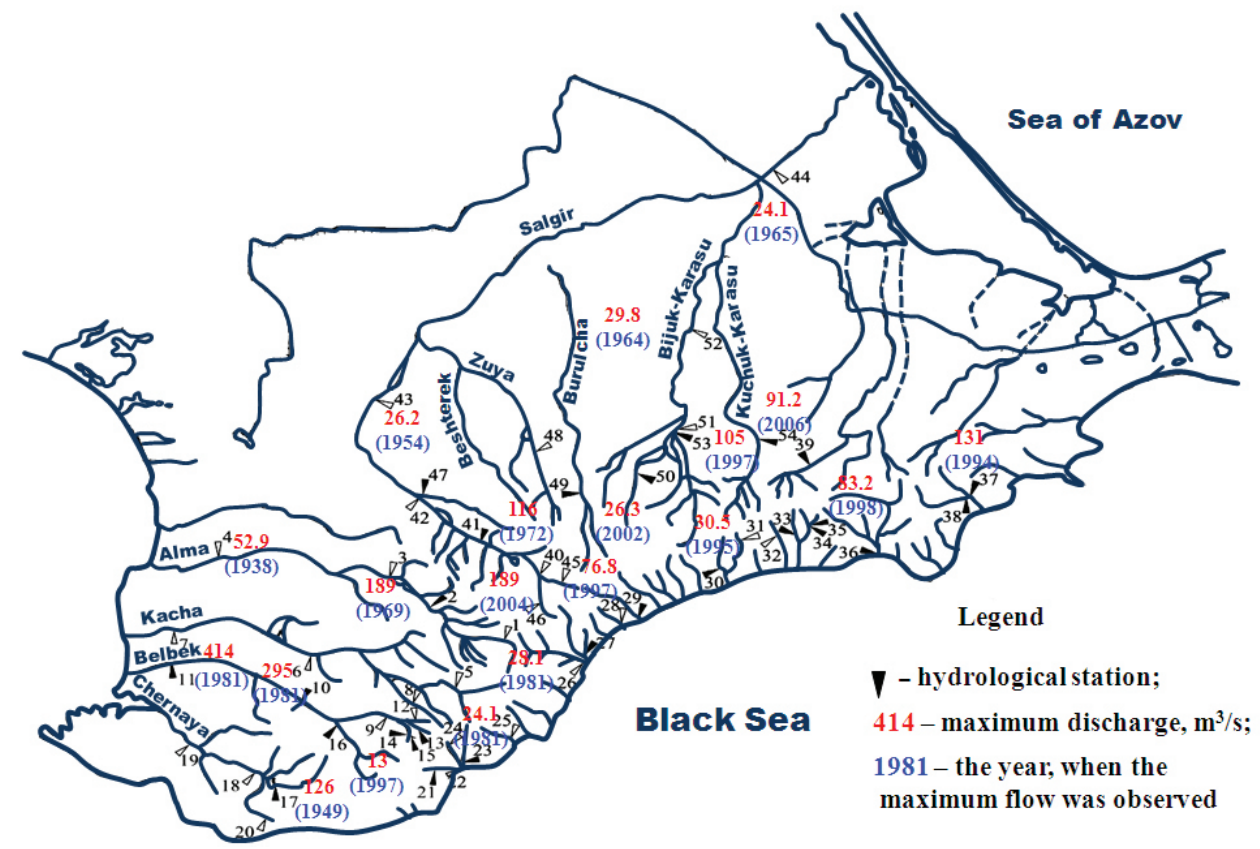

Figure 6. Distribution of maximum water runoff during rain floods over the territory of the Mountainous Crimea for the observation period.

Nevertheless, it is interesting to analyze the number of cases of absolute maximum discharges of rain floods in the warm period on the rivers of the Mountainous Crimea until 1989 (the beginning of the climate change) and after that (Tab. 1).

Analyzing the data in Tab. 1, we can make a clear conclusion that the absolute majority of cases of maximum discharges for the period of observations occurred before 1989. For example, for the rivers at the north-western slope for the period from 1989 to 2010 there were only 2 cases of an absolute maximum which is 9 times less than in the period from the beginning of the observations

Table 1. Number of cases of absolute maximum discharges in the warm period on the rivers at the Crimean Mountains.

\begin{tabular}{lcc}
\hline \multirow{2}{*}{ The slopes of the Crimean Mountains } & \multicolumn{2}{c}{ Number of cases } \\
\cline { 2 - 3 } & until 1989 & after 1989 \\
\hline North-western & 18 & 2 \\
North-eastern & 11 & 5 \\
Southern coast of Crimea & 12 & 6 \\
\hline
\end{tabular}


till 1989. A similar pattern is observed at two other slopes of the Mountainous Crimea where the number of cases in the period after 1989 decreased by almost 2 times. Thus, at present, the existing trends in meteorological factors did not lead to an increase in the cases of catastrophic floods on the rivers in the Mountainous Crimea.

In order to substantiate the calculation parameters a standard statistical processing of the initial information on the maximum river runoff during floods in the given territory was performed. As a result, we obtain the average longterm values of maximum water discharges and runoff depths, as well as the relevant coefficients of variation and asymmetry. The water discharges and runoff depths of rare probability of excess $(P=1,3,5$, and $10 \%)$ were also determined (Ovcharuk et al., 2018).

To assess the statistical homogeneity of the initial information three criteria were used: F-test (Fisher criterion), Student's t-test and Wilcoxon criterion on $5 \%$ significance level. Analyzing the results of the homogeneity estimation it should be noted that the characteristics of rain floods on the Crimean rivers in most cases are homogeneous in time. Based on three criteria, the maximum discharges during rain floods are homogeneous in 21 cases out of 23 ; it means that $91.3 \%$ of series are homogeneous. A similar situation is observed for the series of rain flood layers - which are homogeneous in 20 cases out of 22 based on the three criteria (91\%) (Ovcharuk and Todorova, 2016). The examples of time series maximal runoff are representing on Fig. 7. On the whole, the information on the maximal runoff during rain floods should be considered homogeneous.

Based on the data of statistical processing, as well as on the analysis of conditions for the flood formation in the warm period, all parameters in the form of calculated dependences for the studied area are determined and generalized. The runoff depths $\left(Y_{1 \%}\right)$ are generalized as dependencies on the average altitude of the catchment areas as well as duration of the slope inflow. The unevenness factor is averaged at the level of 16.0. By the instrumentality of formula (2), the calculated maximal slope modulus of $1 \%$ for the territory of the Mountainous Crimea is rated in the form of a schematic map (Gopchenko et al., 2018).

Analysis of the results makes it possible to note that the calculated boundary modular of the slope inflow in the study region as a whole increases from northeast to south from $0.5 \mathrm{~m}^{3} /\left(\mathrm{s} \cdot \mathrm{km}^{2}\right)$ to $10-15 \mathrm{~m}^{3} /\left(\mathrm{s} \cdot \mathrm{km}^{2}\right)$ (Gopchenko et al., 2018; Ovcharuk et al., 2018). Local maxima and minima are observed an active discharge of karst waters and observed values reach $20 \mathrm{~m}^{3} /\left(\mathrm{s} \cdot \mathrm{km}^{2}\right.$ ) (at the Chorna and Voron rivers). On the other hand, minimum values of the maximum modulus of the slope inflow ranging from $0.5 \mathrm{~m}^{3} /\left(\mathrm{s} \cdot \mathrm{km}^{2}\right)$ to $2.5 \mathrm{~m}^{3} /\left(\mathrm{s} \cdot \mathrm{km}^{2}\right)$ are related to feeding of the karst zones.

As mentioned above, in the area under consideration floods can also be observed during the cold season. Therefore, in this study by a similar procedure the 
a)
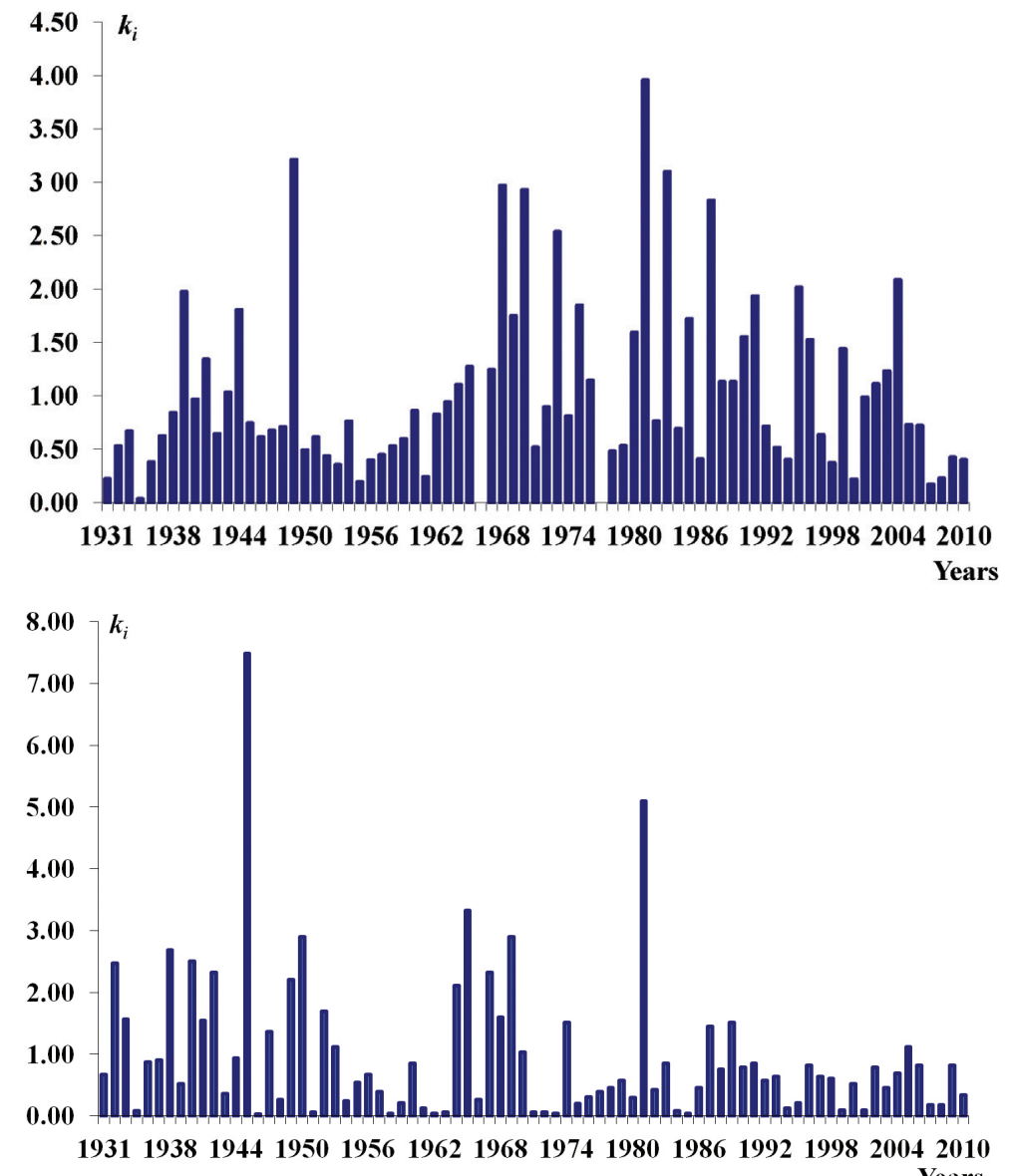

Figure 7. The time series of maximum water discharges $(a)$ and depth of runoff $(b)$ at the river Derekoika in Yalta (in the modular coefficients).

maximum modules of the slope inflow during the floods in cold season were determined whereupon they were generalized as a spatial distribution map (Fig. 8).

Analyzing the obtained map, it can be noted that in accordance with Fig. 2, the calculated values of the module of the slope inflow are significantly lower than the similar values in the warm period of the year but at some watersheds they can reach quite high values - up to $10 \mathrm{~m}^{3} /\left(\mathrm{s} \cdot \mathrm{km}^{2}\right)$.

In the second variant, a factor of the underlying surface which includes the influence of karst and altitude on the maximum slope inflow modulus is introduced in the calculation formula (Ovcharuk and Todorova, 2013). For the ungauged rivers, a coefficient of the underlying surface is presented in the form of a map (Fig. 9). 


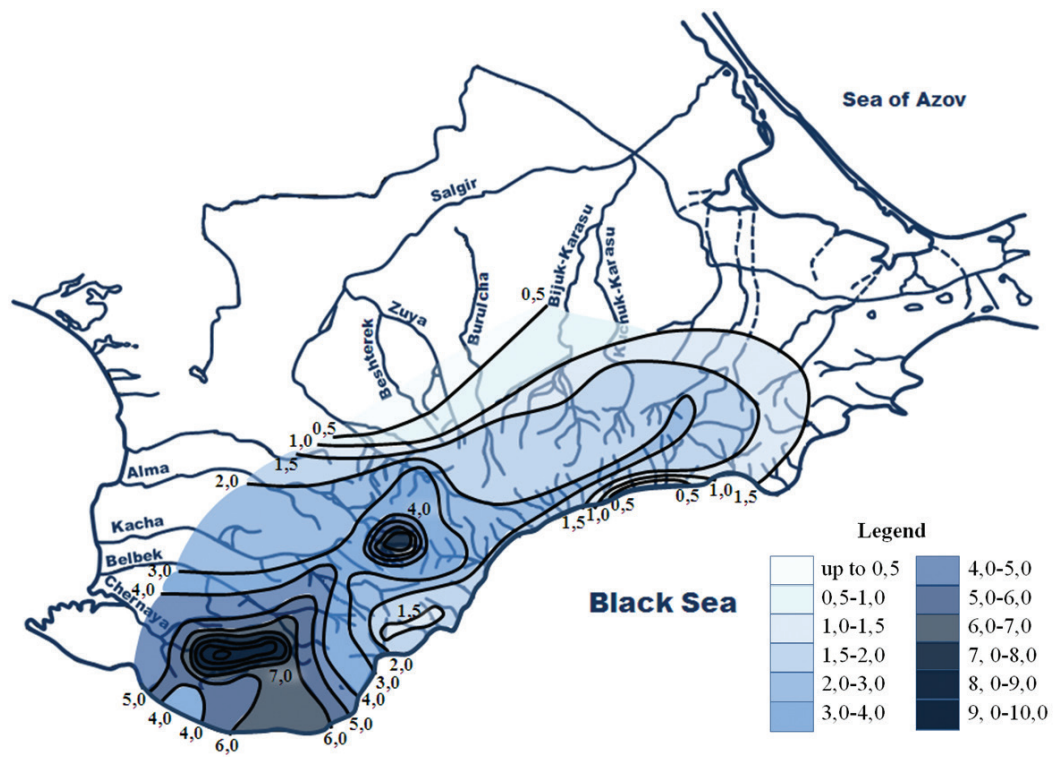

Figure 8. Distribution of the maximum slope modulus with $1 \%$ probability of excess in the cold season at the territory of the Crimean Mountains $\left(\mathrm{m}^{3} /\left(\mathrm{s} \cdot \mathrm{km}^{2}\right)\right)$.

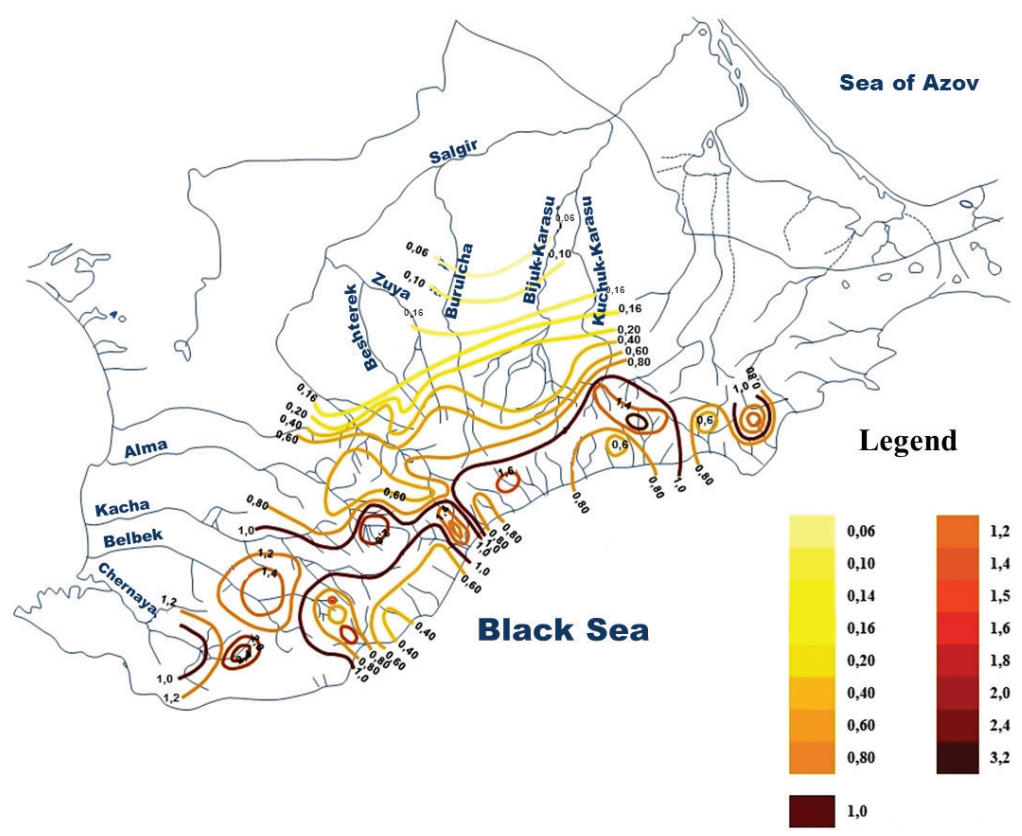

Figure 9. Distribution of coefficients of the underlying surface for the territory of the Crimean Mountains. 
The obtained values range from 0.06 to 3.20 and, in our opinion, reflect the integral effects of karst and peculiarities of the underlying surface that may be related to water management in the catchment area. The coefficients comprising approximately 1.0 indicate that there is no influence of the underlying surface on the studied value.

For an objective assessment of the accuracy of calculation of the maximum water discharges of various probabilities of excess it is necessary to determine their mean-square error. The quadratic mean error of quantiles is determined by means of the Pearson Type III curve, based on the first two sample statistical moments and the given correlation between the variation and asymmetry coefficients by the method of Alekseev (1969):

$$
\sigma_{Q_{1 \%}}=\frac{100}{Q_{P_{1 \%}}} \sqrt{\left(1+C_{v} \Phi_{P_{1 \%}}\right)^{2} \frac{C_{v}^{2} \bar{Q}_{m}^{2}}{n}+\left(\Phi_{P_{1 \%}}+C_{s} \frac{d \Phi_{p}}{d C_{s}}\right) \cdot C_{v}^{2} \bar{Q}_{m}^{2} \cdot\left(\frac{C_{v}^{2}}{n}+\frac{1+0.75 C_{s}^{2}}{2 n}-\frac{C_{s} C_{v}}{n}\right)},
$$

where $n$ is a number of observation years; $C_{s}, C_{v}$ - distribution parameters.

According to the calculations by the formula (6), the accuracy of data on the maximum runoff during floods in the warm period at the rivers of the Crimean Mountains is equal to $\pm 21,6 \%$.

The reliability of the proposed method can be estimated by the formula:

$$
\Delta q_{1 \%}=\frac{\left|q_{1 \%}-q_{1 \%_{i}}\right|}{q_{1 \%_{i}}} \cdot 100 \%
$$

where $q_{1 \%}$ is the values obtained as a result of verified calculations by the method; $q_{1 \%_{i}}$ is the actual values obtained from the initial data. Thus, the average accuracy of the calculation by two methods is at the level of $\pm 21,3 \%$.

In order to compare the obtained results, Tab. 2 gives the maximum water discharges with the $1 \%$ probability calculated according to the suggested meth-

Table 2. Comparison of the maximum water discharges obtained by means of various methods for the rivers at the Crimean Mountains.

\begin{tabular}{lccc}
\hline & \multicolumn{3}{c}{$Q_{1 \%}\left(\mathrm{~m}^{3} / \mathrm{s}\right)$} \\
\cline { 2 - 4 } River - Station & $\begin{array}{c}\text { According to } \\
\text { statistical processing } \\
\text { as of } 2010\end{array}$ & $\begin{array}{c}\text { The largest value } \\
\text { for the whole period } \\
\text { of observation }\end{array}$ & $\begin{array}{c}\text { By the suggested } \\
\text { method, according to } \\
\text { the formula (1) }\end{array}$ \\
\hline Derekoika r. - Yalta st. & 31.04 & 28.1 & 30.8 \\
Chorna r. - Rodnykivske st. & 108.5 & 126 & 121.4 \\
Avunda r. - Hurzuf st. & 9.82 & 11 & 10.6 \\
\hline
\end{tabular}


odology, the similar values obtained according to the statistical processing data as of 2010, as well as the largest discharges for the entire period of observations.

Comparison of the calculated maximum water discharges $(P=1 \%)$ shows the good convergence both with the initial information and with the largest maximum water discharge for the observation periods.

\section{Conclusions}

- In the Mountainous Crimea formation of flash floods is associated with storm rain and meltwater rain, which covers relatively small areas of the territory but can lead to catastrophic consequences. One of the main factors of flood formation in the Mountain Crimea rivers is the underlying surface, especially karst.

- At present time the existing trends in meteorological factors did not lead to an increase in the cases of catastrophic floods on the rivers at the Mountainous Crimea despite the global and regional climate changes.

- Analysis of the scientific and methodological base for calculation of maximum runoff on study area shows that it is not well-grounded and needs improvement.

- The rationing of maximum runoff characteristics during flash floods of different origins at the rivers in the Mountainous Crimea is based on a modified reduction structure that was derived directly from the model of channel isochrones.

- Two variants of the calculation method of the maximum runoff during both a rain and meltwater rain floods in the Crimean Mountains are suggested in the paper. In both variants, the main calculation parameter in the method is the maximal slope modulus, which is generalized in the form of a map. For the case of the rain flood the calculation formula also includes a coefficient of the underlying surface taking into account the karst influence.

- Comparison the calculation of proposal method maximum water discharges rare probability of exceedance shows the good convergence both with the initial information and with the largest maximum water discharge for the observation period. This result makes it possible to recommend the methodology for application into water management practice in Mountainous Crimea.

\section{References}

Alekseev, G. A. (1969): Objective statistical methods for calculating and generalizing the parameters of the maximum rainfall flow, International Symposium on floods and its calculations, L.: Gidrometeoizdat, Part I, 114-129 (in Russian).

Bergstorm, S. (1992): The HBV model - Its Structure and applications, SMHI Reports RH, 4, Norrkoping, $35 \mathrm{pp}$.

Gopchenko, E. D., and Ovcharuk, V. A. (2006): Theoretical ground of normative base for calculation of the characteristics of the maximal runoff and its practical realization, in: Transboundary Floods: Reducing Risks through Flood Management, edited by Marsalek J., Stancalie, G., Balint, G. Springer, 91-99. 
Gopchenko, E. D., Ovcharuk, V. A. and Romanchuk, M. E. (2015): A method for calculating characteristics of maximal river runoff in the absence of observational data: Case study of Ukrainian rivers, Water Resour., 42, 285-291, https://doi.org/10.1134/S0097807815030057.

Gopchenko, E., Ovcharuk, V., Shakirzanova, J., Goptsiy, M., Traskova, A., Shvec, N., Serbova, Z. and Todorova, O. (2018): Modelling of extreme floods on example of mountain regions of Ukraine, in: Visnyk of Taras Shevchenko National University of Kyiv: Geology, 3(82), 6-15, https://doi. org/10.17721/1728-2713.82.01 (in Ukrainian).

Gorbachova, L.O. and Nabyvanets, Y. B. (2012): Forecasted estimations of runoff change in the Dniester Basin under conditions of climate change, EGU Leonardo Conference Hydrology and Society, Torino, Italy.

Hrebin, V. V. (2010): Modern water regime of the rivers of Ukraine (Landscape-hydrological analysis), Kyiv, 316 pp (in Ukrainian).

Kan, G., He, X., Ding, L., Li, J., Liang, K. and Hong, Y. (2017): Study on applicability of conceptual hydrological models for flood forecasting in humid, semi-humid, semi-arid and arid basins in China, Water, 9, 719, http://doi.org/10.3390/w9100719.

Kyndiuk, B. V. (2003): Hydrographic network and storm drainage of the rivers of the Ukrainian Carpathians. Odessa, 219 pp (in Russian).

Loboda, N. S. and Bozhok, Y. V. (2016): Ukrainian water resources of the XXI century under climate change scenarios (RCP 8.5 and RCP 4.5), Ukr. Gìdrometeorol. Ž., Odessa, 114-122 (in Ukrainian).

Ovcharuk, V. A. and Todorova, Y. I. (2013): Research of karst's influence on the characteristics of slope runoff during floods on the rivers of north-western slope of Crimean Mountains, Research Bulletin World "Modern Scientific Research and their Practical Application», J11302-012.

Ovcharuk, V. and Todorova, O. (2016): Determination of characteristics maximal runoff mountain rivers in Crimea, J. Fundam. Appl. Sci., 28, 525-541, https://doi.org/10.4314/jfas.v8i2.23.

Ovcharuk, V., Todorova, E. and Myrza, E. (2018): The maximum runoff of small rivers of the Mountainous Crimea flowing into the Black Sea in modern climatic conditions, 2nd Baltic Sea in Transition, Helsingor, Denmark, 162-163.

Ovcharuk, V. A. and Hopchenko, Y. D. (2018): The modern method of maximum spring flood runoff characteristics valuation for the plain rivers of Ukraine, Ukr. Geogr. $\check{Z}$., N2, 26-33, https://doi. org/10.15407/ugz2018.02.026.

Sajikumar, N. and Thandaveswara, B. (1999): A nonlinear rainfall runoff model using an artificial neural network, J. Hydrol., 216, 32-35, https://doi.org/10.1016/S0022-1694(98)00273-X.

Singh, V. P. (1988): Hydrologic systems. Rainfall-runoff modeling. Englewood Cliffs, Prentice Hall, 480 pp.

Tokar, A. S. and Markus, M. (2000): Precipitation runoff modelling using artificial neural networks and conceptual models, J. Hydro. Eng., 5, 156-161, https://doi.org/10.1061/(ASCE)10840699(2000)5:2(156).

Zaikov, B. D. (1944): Annual river flow distribution in Europe. Proceedings of NIU GUGMS, Moscow, Sverdlovsk: Gidrometeoizdat, IV(15), 50 pp (in Russian).

Zhao, R., Yilin, Z. and Lerun, F. (1980): The Xinanjiang model. J. Proc. Oxf. Symp. Hydrol. Forecast. IAHS Publ., 135, 371-381.

\title{
SAŽETAK
}

\section{Karakteristike naglih poplava malih rijeka planinskog Krima}

\author{
Valeriya Ovcharuk, Eugene Gopchenko, Olena Todorova i Kateryna Myrza
}

Maksimalno površinsko otjecanje s područja krimskih planina prikazano je kao otjecanje malih rijeka koje teku kroz zapadni i istočni dio sjeverne padine te s južne obale. Podaci 54 vodomjerne postaje (WGS) korišteni su za opisivanje maksimalnog otjecanja 
tijekom riječnih poplava uzrokovanih kišama i topljenjem snijega na krimskim planinama. Modificirani oblik redukcijske formule korišten je za procjenu maksimalnog otjecanja pri naglim poplavama rijeka u planinskom području Krima. Glavni parametri predloženog modela mogu se prikazati u ovisnosti o prosječnoj nadmorskoj visini sliva $u$ formi karata. Druga mogućnost predložene metode je uzimanje u obzir same podloge. Usporedba izračunatih vrijednosti maksimalnog otjecanja konzistentna je s inicijalnim podacima i s najvećim vrijednostima u promatranom razdoblju.

Ključne riječi: maksimalno otjecanje, nagla poplava, izokrona

Corresponding author's address: Dr Valeriya Ovcharuk, http://orcid.org/0000-0001-5654-3731; e-mail: valeriya.ovcharuk@gmail.com

(cc) BY-NC This work is licensed under a Creative Commons Attribution-NonCommercial 4.0 International License. 